\title{
THE EFFECT OF EXTRACTION PARAMETERS ON ANTIOXIDANT ACTIVITY OF SUBCRITICAL WATER EXTRACTS OBTAINED FROM MANDARIN PEEL
}

\author{
Evrim Özkaynak Kanmaz*1, Özlem Saral ${ }^{2}$
}

\author{
${ }^{1}$ Artvin Coruh University, Faculty of Health Sciences, Nutrition and Dietetics Department, Turkey \\ ${ }^{2}$ Recep Tayyip Erdoğan University, Health College, Nutrition and Dietetics Department, Turkey
}

Geliş / Received: 14.07.2016; Kabul / Accepted: 04.04.2017; Online bask1 / Published online: 22.04.2017

Kanmaz Özkaynak, E., Saral, Ö. (2017). The effect of extraction parameters on antioxidant activity of subcritical water extracts obtained from mandarin peel. GIDA (2017) 42 (4): 405-412 doi: 10.15237/gida.GD16073

\begin{abstract}
Mandarin peel, which discarded as by-product at large amounts during fruit juice production, is a valuable source of antioxidant compounds in the food industry. The aim of this study was to investigate the effect of extraction temperature and static extraction time on antioxidant activity and phenolic compounds during subcritical water extraction. The antioxidant activity of subcritical water extracts were determined by 1,1-diphenyl-2-picrylhydrazyl (DPPH) assay as $\mathrm{IC}_{50}$, ferric ion reducing antioxidant power (FRAP) and total antioxidant potential assay using $\mathrm{Cu}(\mathrm{II})$ complex as an oxidant (CUPRAC). As the $\mathrm{IC}_{50}$ value of the subcritical water extracts obtained from mandarin peel decreased 40.8 times, FRAP and CUPRAC values increased 66.9 and 34.2 times with increasing extraction temperature from 50 to $180^{\circ} \mathrm{C}$ for $5 \mathrm{~min}$, respectively. Besides, total phenolic content (TPC) of subcritical water extracts increased 4.9 and 5.0 times from 50 to $180^{\circ} \mathrm{C}$ for 5 and 15 min whereas, 9.6 and 9.9 times increase was obtained for total flavonoid content (TFC) in the subcritical water extracts, respectively.
\end{abstract}

Keywords: Subcritical water extraction, antioxidant activity, mandarin peel, phenolics, flavonoids.

\section{MANDALINA KABUĞUNDAN ELDE EDILEN KRİTIK ALTI SU EKSTRAKTLARININ ANTIOKSIDAN AKTIVITE DÜZEYINE EKSTRAKSIYYON PARAMETRELERINIIN ETKISII}

\section{$\ddot{O} \mathbf{z}$}

Meyve suyu üretimi sırasında fazla miktarda yan ürün olarak açığa çıkan mandalina kabuğu gıda endüstrisinde içerdiği antioksidan bileşikler açısından önemli bir kaynaktır. Bu çalışmanın amacı, mandalina kabuğundan kritik altı su ekstraksiyonu tekniği ile elde edilen su ekstraktlarının antioksidan aktivite ve fenolik bileşik içeriğine ekstraksiyon sıcaklığının ve statik ekstraksiyon süresinin etkisini araştırmaktır. Kritik altı su ekstraktlarının antioksidan aktivitesi 1,1-difenil-2-pikrilhidrazil (DPPH)-IC 50 yöntemi, demir iyonu indirgeyici antioksidan güç (FRAP) yöntemi ve oksidan olarak bakır (II) kullanan toplam antioksidan (CUPRAC) yöntemi ile belirlenmiştir. 5 dakika statik ekstraksiyon süresi için ekstraksiyon sıcaklığının $50^{\circ} \mathrm{C}$ 'den $180^{\circ} \mathrm{C}$ 'ye yükselmesi ile mandalina kabuğundan elde edilen kritik altı su esktraktlarının $\mathrm{IC}_{50}$ değerleri 40.8 kat düşmüş olup FRAP ve CUPRAC değerleri ise sırası ile 66.9 and 34.2 kat artmıştır. Ayrıca, kritik altı su esktraktlarının toplam fenolik madde (TPC) içeriği ekstraksiyon sıcaklığının $50^{\circ} \mathrm{C}$ 'den $180^{\circ} \mathrm{C}$ ye yükselmesi ile 5 ve 15 dakika statik ekstraksiyon sürelerinde sırası ile 4.9 ve 5.0 kat artmıştır. Buna karşın, ekstraksiyon sıcaklığının $50^{\circ} \mathrm{C}$ 'den $180^{\circ} \mathrm{C}$ 'ye yükselmesi ile 5 ve 15 dakika statik ekstraksiyon sürelerinde kritik altı su esktraktlarının toplam flavonoit içeriklerinde (TFC) sırası ile 9.6 ve 9.9 kat artış elde edilmiştir.

Anahtar kelimeler: Kritik altı su ekstraksiyonu, antioksidan aktivite, mandalina kabuğu, fenolikler, flavonoitler.

* Yazışmalardan sorumlu yazar / Corresponding author;

(1) evrimka2000@yahoo.com, (c) (+90) $4662151063 / 2127$ ，且 (+90) 4662151064 


\section{INTRODUCTION}

In the last years, novel sustainable extraction techniques such as Ultrasound-Assisted Extraction (UAE), Microwave-Assisted Extraction (MAE), Supercritical CO2 Extraction, Supercritical Fluid Extraction (SFE), Accelerated Solvent Extraction (ASE) and Pressurized Hot Water Extraction (PHWE) or Subcritical Water Extraction (SWE) which allow to reduce extraction time and solvent consumption, increase nutraceutical yield and improve plant extract quality (1-10). Subcritical water extraction is called green technology because it is a rapid and efficient recovery method as compared with conventional extraction methods. During the subcritical water extraction, water was kept in the liquid form using high pressure and high extraction temperature below its critical point, $273^{\circ} \mathrm{C}$. Because of that, the solubility of less polar compounds increase at high temperatures during the subcritical water extraction. In the literature, subcritical water extraction is reported to have high extraction yields and short extraction times as compared conventional extraction methods. In the literature, antioxidant compounds from different food materials were successfully extracted with subcritical water, which is nontoxic extraction solvent (11-14).

Mandarin peel is discarded as by product during mandarin juice or mixed fruit juice production in the food industry and a rich source of especially flavonoids and phenolic acids $(11,15,16)$. Nowadays, extraction studies of natural antioxidant compounds from various food waste products and also citrus peels have been increased. However, organic toxic solvents were used in the most of these studies. On the other hand, especially for human consumption as dietary supplements or food additives, several new techniques have been used and one of them is subcritical water extraction.

In the literature, there is lack of publication regarding the effect of extraction parameters on antioxidant activities of subcritical water extracts obtained from mandarin peel. Therefore, the objective of this study was to investigate the effect of extraction temperature and static extraction time on antioxidant activity and phenolic compounds during subcritical water extraction using accelerated solvent extractor, ASE 350 and also subcritical water extracts and solvent extracts from mandarin peel were compared for extraction efficiency. Besides, the correlation coefficients between phenolic compounds and antioxidant activities of subcritical water extracts obtained from mandarin peel were investigated in this study.

\section{MATERIAL AND METHOD}

\section{Material}

Domestic mandarin (Citrus reticulata) peels were used in this study. Mandarins were cultivated with natural farming using only goat fertilizer in the red and stony soil. Mandarins were harvested in November 2014 from a natural orchard by the Kızan mountainfoot in Köyceğiz, Muğla. The orange coloured mandarin peels were not covered with wax and they were peeled with a stainless steel knife and then dried in the vacuum air oven at $50^{\circ} \mathrm{C}$ until constant weight. Dried mandarin peels were vacuum packed for prevention of oxidation and then stored at $-20^{\circ} \mathrm{C}$ until the extraction process. Samples were ground with a coffee grinder (Bosch, KM 13) between 600 and $1500 \mu \mathrm{m}$ just before extraction.

The chemicals and reagents used in this study were Folin-ciocalteau phenol reagent, luteolin, aluminium chloride, sodium hydroxide, methanol, ethanol, acetone, DPPH, acetate buffer, hydrochloric acid, 2,4,6-tripyridyl-s-triazine (tptz), iron (III) chloride hexahydrate, iron(II) sulfate heptahydrate, copper(II) chloride, neocuproine, ammonium acetate, trolox (Sigma); sodium carbonate, sodium nitrite (Merck); ferrulic acid (Fluka). All the chemicals and solvents used were of analytical or HPLC grade.

\section{Method}

\section{Solvent extraction by magnetic stirrer}

Solvent extraction of mandarin peel was carried out using magnetic stirrer and applied according to the method of Çam and Hişıl (17). 1 gram of mandarin peel was mixed with $10 \mathrm{~mL}$ of organic solvent as methanol, ethanol and acetone at $40^{\circ} \mathrm{C}$ for $1 \mathrm{~h}$ using three magnetic stirrer and the supernatants were filtered and these processes were applied two times and the collected supernatants were adjusted to $25 \mathrm{~mL}$ in this study. Then, the solvent extracts were stored at $-20^{\circ} \mathrm{C}$. The extraction procedure was carried out two times. 


\section{Subcritical water extraction}

In this study, six extraction temperatures (50, 100, $120,140,160$ and $180^{\circ} \mathrm{C}$ ) and two static extraction times ( 5 and $15 \mathrm{~min}$ ) were studied to determine the effect of extraction temperature and static extraction time on phenolics, flavonoids and antioxidant activities of subcritical water extracts. The subcritical water extracts were obtained from mandarin peel using accelerated solvent extractor (ASE 350, Dionex Corporation). The subcritical water extraction was carried out in 25 $\mathrm{ml}$ metal extraction cell, at constant pressure of 1500 psi, fresh water of 5\% and sample amount of $1.5 \mathrm{~g}$. The all subcritical water extracts were obtained at one cycle by accelerated solvent extractor. The extraction procedure was carried out two times.

\section{Determination of antioxidant activities}

The Ferric Reducing Antioxidant Assay (FRAP) was carried according to the method of Benzie and Strain (18). FRAP reagent was prepared by mixing $25 \mathrm{~mL}$ of $300 \mathrm{mM}$ acetate buffer ( $\mathrm{pH}$ 3.6) with $2.5 \mathrm{~mL}$ of $10 \mathrm{mM}$ 2,4,6-tripyridyl-s-triazine (tptz) solution in $0.5 \mathrm{~mL}$ of $\mathrm{HCl}(40 \mathrm{mM})$ and $2.5 \mathrm{~mL}$ of $20 \mathrm{mM}$ iron (III) chloride hexahydrate solution. 3 mL FRAP reagent was mixed with 100 $\mu \mathrm{L}$ of sample extract and incubated at $37^{\circ} \mathrm{C}$ for 4 min. Absorbance of the solutions was measured by a Shimadzu UV-VIS 1800 spectrophotometer at $595 \mathrm{~nm}$ against a reagent blank containing distilled water. Trolox was used a positive control to construct a reference curve $(62.5-1000 \mu \mathrm{M})$. FRAP values were expressed as $\mu$ mol iron (II) sulfate heptahydrate equivalent of $\mathrm{g}$.

The scavenging activity of DPPH radical was determined using the method of Molyneux (19). $1.5 \mathrm{~mL}$ of the sample extract was mixed with 1.5 $\mathrm{mL}$ of DPPH (0.1 mM in methanol), vortexed and incubated at room temperature in the dark for 50 min. Absorbance of the solutions was measured by spectrophotometer at $517 \mathrm{~nm}$. Besides, the control solution without sample extract was used. The results were expressed as $\mathrm{IC}_{50}$ $(\mathrm{mg} / \mathrm{mL})$, which was calculated from the curves by plotting absorbance values. $\mathrm{IC}_{50}$ values represent the concentration of the extract $(\mathrm{mg} / \mathrm{mL})$ required to inhibit $50 \%$ of the radicals.
The cupric reducing antioxidant capacity (CUPRAC) was determined according to the method of Apak et al. (20). $1 \mathrm{~mL}$ of Copper(II) chloride solution $\left(1.0 \times 10^{-2} \mathrm{M}\right), 1 \mathrm{~mL}$ of ethanolic neocuproine solution $\left(7.5 \times 10^{-3} \mathrm{M}\right)$ and $1 \mathrm{~mL}$ of ammonium acetate (1M, pH 7.0) were mixed in a test tube. The sample extract with different concentrations was added to the initial mixture. The tubes were stoppered and the absorbance of the solutions was measured by spectrophotometer at $450 \mathrm{~nm}$ against a reagent blank after $30 \mathrm{~min}$. The result was calculated using the molar absorption coefficient $\left(\varepsilon ; 1.7 \times 104 \mathrm{~L} . \mathrm{mol}^{-1} \cdot \mathrm{cm}^{-1}\right)$ against trolox, which was the standard reference compound. The result was expressed as $\mathrm{mM}$ Trolox/100 g.

\section{Determination of total phenolic and total flavonoid content}

Total phenolic content of subcritical water and solvent extracts were assayed as described by Skerget et al. (21). $0.5 \mathrm{~mL}$ of extract was mixed with $2.5 \mathrm{~mL}$ of $0.2 \mathrm{~N}$ Folin-Ciocalteu reagent and $2 \mathrm{~mL}$ of $7.5 \%$ sodium carbonate and then the solution was incubated at $50^{\circ} \mathrm{C}$ for $5 \mathrm{~min}$ in the water bath (Memmbert, WNB 14) and cooled immediately. The absorbance was measured by spectrophotometer at $760 \mathrm{~nm}$. The calibration curve was prepared with ferrulic acid solutions at five concentrations of aqueous methanol (80\%). The results were expressed as ferrulic acid equivalent (mg of ferrulic acid per L of extract).

Total flavonoid content of subcritical water and solvent extracts were analysed by a spectrophotometric method by Chang et al. (22). $0.5 \mathrm{~mL}$ of extract was mixed with $2.5 \mathrm{~mL}$ of distilled water and $150 \mu \mathrm{L}$ of $5 \%$ sodium nitrite solution. The vortexed solution was allowed to stand for 5 min and then $300 \mu \mathrm{L}$ of $10 \%$ aluminium chloride solution was added to the mixure and allowed to stand for $5 \mathrm{~min}$. Lastly, $1 \mathrm{~mL}$ of $1 \mathrm{M}$ sodium hydroxide was added and $450 \mu \mathrm{L}$ distilled water was added and final solution was vortexed at medium speed. The absorbance was measured by spectrophotometer at $510 \mathrm{~nm}$. The calibration curve was prepared with luteolin solutions at five concentrations aqueous methanol (80\%). The results were expressed as luteolin equivalent (mg of luteolin per L of extract). 


\section{Statistical analysis}

All the analyses were performed in triplicate. Results were expressed as means \pm standard deviation. One-way analysis of variance, least significant difference (LSD) for extraction temperatures and T-test for extraction time and also univariate analysis of variance for the temperature effect, time effect and temperaturetime interaction was applied at significance level 0.05 using SPSS statistical package whereas, Pearson's correlation coefficients were at significance level 0.01 .

\section{RESULTS AND DISCUSSION}

\section{Antioxidant activity of subcritical water extracts from mandarin peel}

As shown from Table 1, the effect of extraction temperature and static extraction time on FRAP, CUPRAC and $\mathrm{IC}_{50}$ values of subcritical water extracts obtained from mandarin peel were statistically significant $(P<0.05)$. Subcritical water extracts from mandarin peel showed higher scavenging activity at higher extraction temperatures. Besides, 15 min as static extraction time was more effective to extract of antioxidant compounds with subcritical water than 5 min (Table 1). The lowest $\mathrm{IC}_{50}$ value and the highest FRAP and CUPRAC value of subcritical water extracts from mandarin peel were determined at $180^{\circ} \mathrm{C}$ for 15 min. Subcritical water extracts from mandarin peel showed scavenging activity against DPPH radical between 37.12 and $0.11 \mathrm{~g} / \mathrm{L}$. As extraction temperature increased from 50 to $180^{\circ} \mathrm{C}, \mathrm{IC}_{50}$ value of subcritical water extracts from mandarin peel decreased 40.8 times (from 37.12 to 0.91 $\mathrm{g} / \mathrm{L}$ ) and 239.4 times (from 26.33 to $0.11 \mathrm{~g} / \mathrm{L}$ ) for 5 and $15 \mathrm{~min}$, respectively. Furtherly, subcritical water extracts at $180^{\circ} \mathrm{C}$ and $15 \mathrm{~min}$ had a high antioxidant activity with the lowest $\mathrm{IC}_{50}$ value $(0.11 \mathrm{~g} / \mathrm{L})$ as compared the $\mathrm{IC}_{50}$ value of trolox (0.06 g/L).

Subcritical water extracts from mandarin peel had the significant $(P<0.05)$ highest FRAP and CUPRAC value at $180^{\circ} \mathrm{C}$ for $15 \mathrm{~min}$, followed by $180^{\circ} \mathrm{C}$ and $5 \mathrm{~min}$. Besides, FRAP and CUPRAC values of subcritical water extracts from mandarin peel increased 66.9 times (from 1.40 to 93.63 $\mu \mathrm{mol} \mathrm{FeSO}_{4} \cdot 7 \mathrm{H}_{2} \mathrm{O} / \mathrm{g}$ ) and 34.2 times (from 2.27 to $77.70 \mathrm{mM}$ troloks/g) with increasing extraction temperature from 50 to $180^{\circ} \mathrm{C}$ for $5 \mathrm{~min}$, respectively. Also, for $15 \mathrm{~min}$, FRAP and CUPRAC values of subcritical water extracts increased 39.9 times (from 3.37 to $134.41 \mu \mathrm{mol} \mathrm{FeSO}_{4} .7 \mathrm{H}_{2} \mathrm{O} / \mathrm{g}$ ) and 24.4 times (from 4.10 to $100.11 \mathrm{mM}$ troloks/g) with increasing extraction temperature from 50 to $180^{\circ} \mathrm{C}$.

Also, static extraction time had a significant $(P<0.05)$ effect on antioxidant activity of subcritical water extracts from mandarin peel. As static extraction time increased from 5 to $15 \mathrm{~min}, \mathrm{IC}_{50}$ value of subcritical water extracts from mandarin peel decreased 6.6 times (from 3.42 to $0.52 \mathrm{~g} / \mathrm{L}$ ) and 8.3 times (from 0.91 to $0.11 \mathrm{~g} / \mathrm{L}$ ) at 160 and

Table 1. Antioxidant activity values of subcritical water extracts from mandarin peel.

\begin{tabular}{|c|c|c|c|c|}
\hline $\begin{array}{c}\text { Extraction } \\
\text { temperature } \\
\left({ }^{\circ} \mathrm{C}\right)\end{array}$ & $\begin{array}{c}\text { Extraction } \\
\text { time } \\
\text { (min) }\end{array}$ & $\begin{array}{c}\text { FRAP } \\
\left(\mu \mathrm{mol} \mathrm{FeSO}{ }_{4} \cdot 7 \mathrm{H}_{2} \mathrm{O} / \mathrm{g}\right)\end{array}$ & $\begin{array}{c}\text { CUPRAC } \\
(\mathrm{mM} \text { troloks } / \mathrm{g})\end{array}$ & $\begin{array}{l}\mathrm{IC}_{50} \\
(\mathrm{~g} / \mathrm{L})\end{array}$ \\
\hline 50 & & $1.40 \pm 0.10^{e}$ & $2.27 \pm 0.09^{e}$ & $37.12 \pm 1.20^{\circ}$ \\
\hline 100 & & $2.53 \pm 0.18^{e}$ & $3.03 \pm 0.10^{d}$ & $32.03 \pm 0.87^{b}$ \\
\hline 120 & & $4.01 \pm 0.09^{d}$ & $3.16 \pm 0.20^{d}$ & $12.74 \pm 2.42^{\circ}$ \\
\hline 140 & 5 & $11.34 \pm 0.11^{c}$ & $9.51 \pm 0.21^{c}$ & $9.59 \pm 1.11^{d}$ \\
\hline 160 & & $25.85 \pm 0.50^{b}$ & $22.94 \pm 0.14^{b}$ & $3.42 \pm 0.72^{\mathrm{e}}$ \\
\hline 180 & & $93.63 \pm 1.86^{a}$ & $77.70 \pm 0.27^{\mathrm{a}}$ & $0.91 \pm 0.03^{\dagger}$ \\
\hline 50 & & $3.37 \pm 0.35^{\mathrm{e}}$ & $4.10 \pm 0.53^{e}$ & $26.33 \pm 0.57^{\mathrm{a}}$ \\
\hline 100 & & $4.63 \pm 0.06^{\mathrm{e}}$ & $4.61 \pm 0.16^{e}$ & $18.23 \pm 0.51^{b}$ \\
\hline 120 & & $12.15 \pm 0.19^{d}$ & $9.98 \pm 0.19^{d}$ & $10.14 \pm 0.09^{\circ}$ \\
\hline 140 & 15 & $14.85 \pm 0.20^{\circ}$ & $12.27 \pm 0.34^{c}$ & $7.48 \pm 0.49^{d}$ \\
\hline 160 & & $90.37 \pm 2.35^{b}$ & $73.96 \pm 0.44^{b}$ & $0.52 \pm 0.04^{\mathrm{e}}$ \\
\hline 180 & & $134.41 \pm 2.23^{a}$ & $100.11 \pm 1.81^{\mathrm{a}}$ & $0.11 \pm 0.00^{\mathrm{e}}$ \\
\hline Trolox & & & $0.06 \pm 0.00$ & \\
\hline
\end{tabular}

Values are means \pm standard deviations of three $(n=3)$ measurements

a.f Values with different superscript letters within a column are significantly different at $P<0.05$ 
Table 2. The Pearson's correlation coefficients* between antioxidant activities and phenolics in the subcritical water extracts from mandarin peel.

\begin{tabular}{lcccc}
\hline Trait & FRAP & CUPRAC & $\mathrm{IC}_{50}$ & TFC \\
\hline $\mathrm{IC}_{50}$ & $-0.68^{*}$ & $-0.69^{*}$ & & $0.99^{*}$ \\
$\mathrm{TPC}$ & $0.99^{*}$ & $0.99^{*}$ & $-0.72^{*}$ & $-0.67^{*}$ \\
TFC & $0.99^{*}$ & $0.99^{*}$ & & \\
CUPRAC & $0.99^{*}$ & & & \\
\hline
\end{tabular}

${ }^{*}$ Correlation is significant at the $P<0.01$ level

$180^{\circ} \mathrm{C}$, respectively. However, FRAP value of subcritical water extracts increased 3.0 times (from 4.01 to $12.15 \mu \mathrm{mol} \mathrm{FeSO}_{4} .7 \mathrm{H}_{2} \mathrm{O} / \mathrm{g}$ ) and 3.5 times (from 25.85 to $90.37 \mu \mathrm{mol} \mathrm{FeSO}_{4} .7 \mathrm{H}_{2} \mathrm{O} / \mathrm{g}$ ) with increasing static extraction time from 5 to 15 min at 120 and $160^{\circ} \mathrm{C}$, respectively. Besides, CUPRAC value of subcritical water extracts from mandarin peel increased 3.2 times (from 3.16 to $9.98 \mathrm{mM}$ troloks/g) and 3.2 times (from 22.94 to $73.96 \mathrm{mM}$ troloks $/ \mathrm{g}$ ) while static extraction time increased from 5 to $15 \mathrm{~min}$ at 120 and $160^{\circ} \mathrm{C}$, respectively.

These results suggested that the compounds capable of reducing DPPH radical in subcritical water extracts from mandarin peel could be extracted with subcritical water at higher extraction temperatures. Rodr guez-Meizoso et al. (23) also reported that the highest antioxidant activity $\left(\mathrm{EC}_{50}\right.$ equal to $\left.10 \mathrm{mg} / \mathrm{L}\right)$ in subcritical water extracts from oregano leave was observed at the highest temperature, $200^{\circ} \mathrm{C}$ and $30 \mathrm{~min}$. Also, Wiboonsirikul et al. (24) determined the highest $\mathrm{EC}_{50}$ value (25 and $22 \mathrm{mg} / \mathrm{L}$, respectively) in subcritical water extracts from oregano leave at 150 and $200^{\circ} \mathrm{C}$ for $15 \mathrm{~min}$ and it was also reported that the radical scavenging activity would resulted from several substances depending upon their water solubility and heat stability.

On the other hand, the correlations between total phenolic contents and antioxidant activities and the correlations between total flavonoid contents and antioxidant activities and also between antioxidant activities of subcritical water extracts from mandarin peel were shown in Table 2. Both FRAP and also CUPRAC values of subcritical water extracts from mandarin peel were significantly $(P<0.01)$ correlated as $r^{2}=0.99$ with total phenolic contents in this study. Also, Tezcan et al. (25) reported that the antioxidant activity, FRAP assay and total phenolic content levels were positively and significantly correlated as $r^{2}>0.98$ in commercial pomegranate juices. Also, Ozgen et al. (26) reported that levels of FRAP and total phenolic content of pomegranate juices were strongly correlated as $r^{2}=0.93$. In this study, total flavonoid content of subcritical water extracts from mandarin peel were also significantly $(P<0.01)$ correlated as $r^{2}=0.99$ with both FRAP and also CUPRAC values.

Besides, in this study, significantly $(P<0.01)$ high correlations between $\mathrm{IC}_{50}$ values with total phenolic and total flavonoid contents were found as $r^{2}=-0.72$ and -0.67 in the subcritical water extracts from mandarin peel, respectively (Table 2). $\mathrm{IC}_{50}$ values showed lower correlation with phenolic compounds than FRAP and CUPRAC values. It can be explained with $\beta$-caroten, essential oils and melanoidins could have higher correlation with DPPH. As seen from Figure 1, melanoidins increased at higher extraction temperatures and also with longer extraction times. Delgado Andrade et al. (27) also reported that coffee melanoidins showed the highest correlation with DPPH.

\section{Subcritical water extraction of phenolic compounds from mandarin peel}

The effect of extraction temperature and static extraction time on total phenolic and total flavonoid content of subcritical water extracts obtained from mandarin peel using accelerated solvent extractor was statistically significant $(P<0.05)$. Total phenolic and total flavonoid content of subcritical water extracts from mandarin peel increased 3.8 times (from 3.52 to 13.40 $\mathrm{mg} / \mathrm{L}$ ) and 3.9 times (from 0.71 to $2.73 \mathrm{mg} / \mathrm{L}$ ) with increasing extraction temperature from 140 to $160^{\circ} \mathrm{C}$ for $15 \mathrm{~min}$, respectively. However, total phenolic and total flavonoid content of subcritical water extracts increased 2.4 times (from 5.50 to $13.40 \mathrm{mg} / \mathrm{L}$ ) and 2.7 times (from 1.01 to 2.73 $\mathrm{mg} / \mathrm{L}$ ) with increasing static extraction time from 

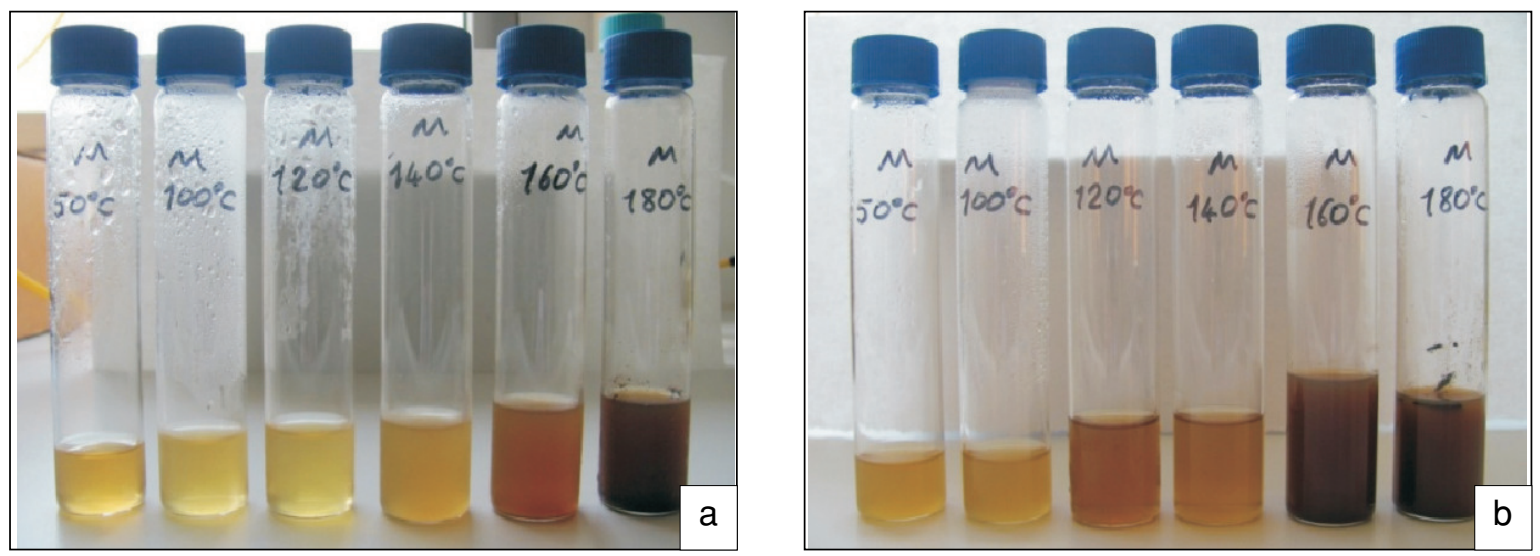

Figure 1. Subcritical water extracts from mandarin peel at $50-180^{\circ} \mathrm{C}$ for 5 (a) and 15 (b) min using accelerated solvent extractor, respectively.

5 to $15 \mathrm{~min}$ at $160^{\circ} \mathrm{C}$. Besides, total phenolic and total flavonoid content of subcritical water extracts from mandarin peel increased 2.2 times (from 5.50 to 12.13) and 2.5 times (from 1.01 to $2.47)$ as extraction temperature increased from 160 to $180^{\circ} \mathrm{C}$ for $5 \mathrm{~min}$, respectively (Table 3 ).

Total phenolic content of subcritical water extracts from mandarin peel increased 9.6 times (from 1.26 to $12.13 \mathrm{mg} / \mathrm{L}$ ) and 9.9 times (from 1.61 to $15.91 \mathrm{mg} / \mathrm{L}$ ) with increasing extraction temperature from 50 to $180^{\circ} \mathrm{C}$ for 5 and $15 \mathrm{~min}$, respectively whereas, total flavonoid content of subcritical water extracts increased 4.8 times (from 0.51 to 2.43) and 5.0 times (from 0.61 to 3.03) for 5 and $15 \mathrm{~min}$, respectively (Table 3 ). The significantly $(P<0.05)$ highest total phenolic and total flavonoid content of subcritical water extracts from mandarin peel were determined at $180^{\circ} \mathrm{C}$ and $15 \mathrm{~min}$ and it was followed by $160^{\circ} \mathrm{C}$ and $5 \mathrm{~min}$ in this study. These results suggested that phenolic acids and flavonoids of mandarin peel could be extracted with subcritical water between 160 and $180^{\circ} \mathrm{C}$ and also high amounts of phenolics especially at $180^{\circ} \mathrm{C}$ might be explained with formation of new phenolic compounds during decomposition of lignans and dietary fibers.

Özkaynak Kanmaz and Ova (12) reported that SDG lignan in subcritical water extracts from flaxseed meal increased 15.6 times from 120 to $180^{\circ} \mathrm{C}$ for $15 \mathrm{~min}$ whereas, there was a significantly $(P<0.05)$ decrease at $180^{\circ} \mathrm{C}$ for 30 min. On the other hand, Özkaynak Kanmaz (13)

Table 3. Total phenolic and total flavonoid content of subcritical water extracts from mandarin peel.

\begin{tabular}{|c|c|c|c|}
\hline $\begin{array}{c}\text { Extraction } \\
\text { temperature }\left({ }^{\circ} \mathrm{C}\right)\end{array}$ & $\begin{array}{l}\text { Extraction time } \\
\qquad(\min )\end{array}$ & $\begin{array}{c}\text { Total phenolic } \\
\text { content }(\mathrm{g} / \mathrm{L})\end{array}$ & $\begin{array}{c}\text { Total flavonoid } \\
\text { content }(\mathrm{g} / \mathrm{L})\end{array}$ \\
\hline 50 & \multirow{6}{*}{5} & $1.26 \pm 0.06^{f}$ & $0.51 \pm 0.04^{\mathrm{e}}$ \\
\hline 100 & & $1.50 \pm 0.04^{\mathrm{e}}$ & $0.55 \pm 0.04^{d}$ \\
\hline 120 & & $1.57 \pm 0.07^{d}$ & $0.53 \pm 0.03^{d}$ \\
\hline 140 & & $2.96 \pm 0.13^{c}$ & $0.72 \pm 0.01^{c}$ \\
\hline 160 & & $5.50 \pm 0.13^{b}$ & $1.01 \pm 0.02^{b}$ \\
\hline 180 & & $12.13 \pm 0.28^{a}$ & $2.47 \pm 0.09^{a}$ \\
\hline 50 & \multirow{6}{*}{15} & $1.61 \pm 0.03^{\dagger}$ & $0.61 \pm 0.03^{d}$ \\
\hline 100 & & $1.90 \pm 0.04^{\mathrm{e}}$ & $0.51 \pm 0.04^{\mathrm{e}}$ \\
\hline 120 & & $2.72 \pm 0.03^{d}$ & $0.63 \pm 0.04^{d}$ \\
\hline 140 & & $3.52 \pm 0.24^{c}$ & $0.71 \pm 0.04^{c}$ \\
\hline 160 & & $13.40 \pm 1.09^{b}$ & $2.73 \pm 0.22^{b}$ \\
\hline 180 & & $15.91 \pm 1.08^{\mathrm{a}}$ & $3.03 \pm 0.07^{\mathrm{a}}$ \\
\hline \multirow[t]{3}{*}{ Organic solvents* } & Methanol & $8.35 \pm 0.70$ & $0.89 \pm 0.02$ \\
\hline & Ethanol & $4.17 \pm 0.32$ & $0.65 \pm 0.01$ \\
\hline & Acetone & $1.94 \pm 0.09$ & $0.54 \pm 0.01$ \\
\hline
\end{tabular}

Values are means \pm standard deviations of three $(n=3)$ measurements

a.f Values with different superscript letters within a column are significantly different at $P<0.05$

${ }^{*} 40^{\circ} \mathrm{C}, 2 \mathrm{~h}$, magnetic stirrer 
reported that the significantly $(P<0.05)$ highest total phenolic and total flavonoid content of subcritical water extracts from flaxseed meal were determined at $180^{\circ} \mathrm{C}$ for $30 \mathrm{~min}$. Besides, Ko et al. (14) studied with subcritical water extraction $\left(110-210^{\circ} \mathrm{C}\right)$ of flavonoids from different materials using accelerated solvent extractor and the highest extracts were obtained for quercetin at $170^{\circ} \mathrm{C} / 10 \mathrm{~min}$ (from onion skins), kaempferol and luteolin at $190^{\circ} \mathrm{C} / 15 \mathrm{~min}$ (from carrots), naringin at $170^{\circ} \mathrm{C} / 10 \mathrm{~min}$ and naringenin at $170-190^{\circ} \mathrm{C} / 15 \mathrm{~min}$ (from grapefruit peels), hesperidin at $170^{\circ} \mathrm{C} / 10 \mathrm{~min}$ (from orange peels) and also hesperetin at $190^{\circ} \mathrm{C} / 10 \mathrm{~min}$ (from lemon peels).

On the other hand, in this study, subcritical water extracts from mandarin peel obtained at $180^{\circ} \mathrm{C}$ and $15 \mathrm{~min}$ had 3.4, 4.7 and 5.6 times higher total phenolic content than methanol, ethanol and acetone extracts, respectively. Besides, total flavonoid content of subcritical water extracts from mandarin peel at $180^{\circ} \mathrm{C}$ and 15 min was 1.9 , 3.8 and 8.2 times higher than methanol, ethanol and acetone extracts, respectively (Table 3 ). These results showed that subcritical water was much more effective than methanol and also methanol was more effective to extract especially flavonoids from mandarin peel than ethanol and acetone solvents. In the literature, Min et al. (28) studied with subcritical water extract from Citrus unshiu peel only at $160^{\circ} \mathrm{C}$ and $15 \mathrm{~min}$ and found that total phenolic and total flavonoid content of subcritical water extract were higher than ethanol and hot water extracts. Cheigh et al. (11) also reported that hesperidin of subcritical water extracts from Citrus unshiu peel were 1.9 and 3.2 times higher than ethanol and methanol extracts, respectively.

\section{CONCLUSION}

Antioxidant activity, total phenolic content and also total flavonoid content of subcritical water extracts from mandarin peel increased with the increase in extraction temperature and static extraction time. The results in this study showed that subcritical water extracts obtained from mandarin peel at $180^{\circ} \mathrm{C}$ and $15 \mathrm{~min}$ are good source for functional foods with high antioxidant activity and phenolic compounds and also subcritical water extracts from mandarin peel at $180^{\circ} \mathrm{C}$ and $15 \mathrm{~min}$ are noticeably important as natural antioxidant.

\section{Acknowledgement}

The author wishes to thank Food Safety an Agricultural Research Center in Akdeniz University for the help using acceleraded solvent extractor, ASE 350 model.

\section{LITERATURE}

1. Munshi P, Bhaduri S. 2009. Supercritical $\mathrm{CO}_{2}$ : A twenty first century solvent for the chemical industry. Curr Sci, 97 (10): 63-72.

2. Teo CC, Tana SN, Hong Yonga JW, Hewb CS, Ong ES. 2010. Pressurized hot water extraction (PHWE). J Chromatogr A, 1217 (16): 2484-94.

3. Pereira CG, Meireles MAA. 2010. Supercritical fluid extraction of bioactive compounds: Fundamentals, applications and economic perspectives. Food Bioprocess Technol, 3(3): 340-372.

4. Ghafoor K, Park J, Choi YH. 2010. Optimization of supercritical fluid extraction of bioactive compounds from grape (Vitis labrusca B.) peel by using response surface methodology. Innovative Food Sci Emerging Technol, 11 (3): 485-490.

5. Pérez-Serradilla JA, Luque de Castro MD. 2011. Microwave-assisted extraction of phenolic compounds from wine lees and spray-drying of the extract. Food Chem, 124 (4): 1652-1659.

6. Carrera C, Ruiz-Rodr guez A, Palma M, Barroso CG. 2012. Ultrasound assisted extraction of phenolic compounds from grapes. Anal Chim Acta, 732: 100-104.

7. Valdes A, Vidal L, Beltrán A, Canals A, Garrigós MC. 2015. Microwave-assisted extraction of phenolic compounds from almond skin byproducts (Prunus amygdalus): A multivariate analysis approach. J Agric Food Chem, 63 (22): 5395-5402.

8. Heffels P, Weber F, Schieber A. 2015. Influence of accelerated solvent extraction and ultrasoundassisted extraction on the anthocyanin profile of different vaccinium species in the context of statistical models for authentication. J Agric Food Chem, 63 (34): 7532-7538.

9. Setyaningsih W, Saputro IE, Barbero GF, Palma M, Barroso CG. 2015. Determination of melatonin in rice (Oryza sativa) grains by pressurized liquid extraction. J Agric Food Chem, 63 (4): 1107-1115. 
10. He B, Zhang LL, Yue XY, Liang J, Jiang J, Gao XL, Yue PX. 2016. Optimization of UltrasoundAssisked Extraction of phenolic compounds and anthocyanins from blueberry (Vaccinium ashei) wine pomace. Food Chem, 2004: 70-76.

11. Cheigh CI, Chung EY, Chung, MS. 2012. Enhanced extraction of flavanones hesperidin and narirutin from Citrus unshiu peel using subcritical water. J Food Eng, 110: 472-477.

12. Özkaynak Kanmaz E, Ova G. 2013. The effective parameters for subcritical water extraction of SDG lignan from flaxseed (Linum usitatissimum L.) using accelerated solvent extractor. Eur Food Res Technol, 237(2): 159-166.

13. Özkaynak Kanmaz E. 2014. Subcritical water extraction of phenolic compounds from flaxseed meal sticks using accelerated solvent extractor (ASE). Eur Food Res Technol, 238: 85-91.

14. Ko MJ, Cheigh CI, Chung MS. 2014. Relationship analysis between flavonoids structure and subcritical water extraction (SWE). Food Chem, 143: 147-155.

15. Hayat K, Hussain S, Abbas S, Farooq U, Ding B, Xia S, Jia C, Zhang X, Xia W. 2009. Optimized microwave-assisted extraction of phenolic acids from citrus mandarin peels and evaluation of antioxidant activity in vitro. Sep Purif Technol, 70: 63-70.

16. Hayat K, Zhang X, Chen H, Xia S, Jia C, Zhong F. 2010. Liberation and separation of phenolic compounds from citrus mandarin peels by microwave heating and its effect on antioxidant activity. Sep Purif Technol, 73: 371-376.

17. Çam M, Hış1 Y. 2010. Pressurized water extraction of polyphenols from pomegranate peels. Food Chem, 123: 878-885.

18. Benzie JFF, Strain, JJ. 1999. Ferric reducing/ antioxidant power assay: direct measure of total antioxidant activity of biological fluids and modified version for simultaneous measurement of total antioxidant power and ascorbic acid concentration. Meth. Enzymology, 299: 15-27.

19. Molyneux. 2004. The use of the stable free radical diphenylpicrylhyrazyl (DPPH) for estimating antioxidant activity. Songklanakarin J Sci Technol, 26: 211-219.
20. Apak R, Güçlü K, Özyürek M, Karademir SE. 2004. Novel Total Antioxidant capacity index for dietary polyphenols and vitamins $\mathrm{C}$ and $\mathrm{E}$, using their cupric ion reducing capability in the presence of neocuproine: CUPRAC Method. $J$ Agric Food Chem, 52: 7970-7981.

21. Skerget M, Kotnik P, Hadolin M, Hras AR, Simonic M, Knez Z. 2005. Phenols, proanthocyanidins, flavones and flavonols in some plant materials and their antioxidant activities. Food Chem, 89: 191-198.

22. Chang CH, Lin HY, Chang CY, Liu YC. 2006. Comparisons on the antioxidant properties of fresh, freeze-dried and hot-air-dried tomatoes. $J$ Food Eng, 77: 478-485.

23. Rodr guez-Meizoso I, Marin FR, Herrero M, Senorans FJ, Reglero G, Cifuentes A, Ibánez E. 2006. Subcritical water extraction of nutraceuticals with antioxidant activity from oregano, Chemical and functional characterization. J Pharm Biomed Anal, 41: 1560-1565.

24. Wiboonsirikul J, Kimura Y, Kadota M, Morita M, Tsuno T, Adachi S. 2007. Properties of extracts from defatted rice bran by its subcritical water treatment. J Agric Food Chem, (55), 8759-8765.

25. Tezcan F, Gultekin-Ozguven M, Diken T, Ozcelik B, Erim B. 2009. Antioxidant activity and total phenolic, organic acid and sugar content in commercial pomegranate juices. Food Chem, 115: 873-877.

26. Ozgen M, Durgaç C, Serçe S, Kaya C. 2008. Chemical and antioxidant properties of pomegranate cultivars grown in the Mediterranean region of Turkey. Food Chem, 111: 703-706.

27. Delgado-Andrade C, Rufián-Henares JA, Morales FJ. 2005. Assessing the Antioxidant Activity of Melanoidins from Coffee Brews by Different Antioxidant Methods. J Agric Food Chem, 53 (20): 7832-7836.

28. Min KY, Lee KA, Kim HJ, Kim KT, Chung MS, Chang PS, Park H, Paik HD. 2014. Antioxidative and anti-inflammatory activities of citrus unshiu peel extracts using a combined process of subcritical water extraction and acid Hydrolysis. Food Sci Biotechno, 23(5): 1441-1446. 